\title{
Carnosinase activity of human gastrointestinal mucosa
}

\author{
F. SADIKALI, R. DARWISH, AND W. C. WATSON \\ From the Gastrointestinal Unit, Victoria Hospital, and Department of Medicine, University of Western \\ Ontario, London, Ontario, Canada
}

SUMmARY Carnosinase, the dipeptidase which hydrolyses carnosine and other histidine-containing dipeptides, was assayed in mucosal tissues of the human and of the rat gut. Kinetic properties of the intestinal enzyme were found to be similar to carnosinase of other animal tissues. Little or no activity was detected in human gastric or colonic mucosa, and the levels were lower in duodenal than jejunal mucosa. The distribution of carnosinase is similar to that of the disaccharidases. Mean carnosinase activity was 8.8 units/g weight in 15 patients with histologically normal mucosa compared with 5.7 units in five with villous atrophy. The enzyme levels increased with histological improvement of the mucosa in patients with coeliac disease on a gluten-free diet. Tolerance curves for carnosine and its constitutent amino acids showed malabsorption of the dipeptide in a patient with carnosinase deficiency. It is concluded that the intestinal mucosa has much less hydrolase activity for carnosine than for glycylglycine and other dipeptidases, and the relatively slow hydrolysis appears to be the rate-limiting step in the total absorptive process.

Although carnosine ( $\beta$-alanyl L-histidine) is one of the few dipeptides found in animal tissues in large quantities, its physiological role is unknown (Yockey and Marshall, 1969). Carnosinase, the enzyme which hydrolyses carnosine and other histidine-containing dipeptides (Smith, 1951), has been detected in organs such as kidney, liver and spleen (Garkavi, 1938), but no activity could be shown in the swine intestinal mucosa (Meshkova and Severin, 1947; Hanson and Smith, 1949). Using a qualitative technique, Wood (1957) was able to demonstrate carnosinase activity in a wide variety of rat tissues, including the intestinal wall. At least five children with a progressive neurological disease and excessive urinary excretion of carnosine have been reported (Perry, Hansen, Tischler, Bunting, and Berry, 1967; Heeswijk, Trijbels, Schretlen, Munster, and Monnens, 1969; Terplan and Cares, 1972). In two of these patients increased serum carnosine levels were found on oral loading with carnosine, and little or no serum carnosinase activity was observed (Perry, Hansen, and Love, 1968). No data are available on carnosinase activity in the mucosa of the gastrointestinal tract in these patients nor in normal subjects.

Received for publication 14 May 1975.
Absorption of carnosine and its constituent amino acids has been studied in man by Asatoor, Bandoh, Lant, Milne, and Navab (1970), whose data suggest that although carnosine is taken up intact by intestinal cells, subsequent hydrolysis is a relatively slow process. In view of the importance of peptide hydrolases of the small intestinal mucosa in the final phases of protein digestion (Newey and Smyth, 1960; Crane, 1961; Rhodes, Eichholz, and Crane, 1967; Matthews, 1971), we have studied the intestinal carnosinase of the rat and of the human subject in both normal and various disease states. The role of this dipeptidase for absorption of L-carnosine was tested by comparing the tolerance curves for the dipeptide and its constituent amino acids in two patients, one of whom had a markedly reduced activity of jejunal carnosinase.

\section{Patients and Methods}

Biopsies were taken from endoscopically normal mucosa of the stomach, duodenum and colon of patients undergoing diagnostic endoscopy for symptoms unconnected with small bowel function. The sites chosen were the middle part of the body of the stomach on its lesser curve, the second part of the duodenum, and various parts of the colon. 
Jejunal mucosal tissue was available from a series of patients who were being investigated for a variety of gastrointestinal disorders-mainly diarrhoea or malabsorption. In these patients peroral jejunal biopsies were taken with a Crosby capsule from the proximal jejunum, usually within 5 to $6 \mathrm{~cm}$ of the ligament of Treitz. All jejunal biopsies were examined under the dissecting microscope and parts of each specimen histologically also.

Carnosinase activity was quantitatively assayed using a modification of the method described for other peptide hydrolases (Sadikali, 1971). In preliminary experiments with rat and human jejunal tissue it was found that carnosinase activity was only about $1 / 10$ of that for glycylglycine dipeptidase. Therefore more tissue was required and incubation had to be carried out for three hours. Biopsies were weighed and homogenized with a glass homogenizer in $0.18 \mathrm{M}$ borate buffer ( $\mathrm{pH} \mathrm{8.0)}$ containing $0.0017 \mathrm{M}$ manganese sulphate. The concentration of mucosal tissue in the homogenate was generally 1 in 40 . Assays of enzyme activity were carried out on the same day in all cases. In 17 cases enough tissue was available to estimate hydrolase activity for homocarnosine ( $\gamma$-amino butyryl L-histidine) as well as carnosine. To $100 \mu \mathrm{l}$ of the homogenate $50 \mu \mathrm{l}$ of the borate buffer was added and incubated at $40^{\circ} \mathrm{C}$. At zero time $100 \mu \mathrm{l}$ of the crude homogenate was added and 10- $\mu$ l samples were withdrawn at 0 , one, two, and three hours. Enzyme activity was estimated by the increase in ninhyrin colour (Matthews, Muir, and Baron, 1964) as described previously (Sadikali, 1971). Carnosinase was determined as units/g wet weight of the mucosa, one unit being defined as the enzyme activity hydrolyzing one $\mu$ Mole of the dipeptide per minute at $40^{\circ} \mathrm{C}$. Carnosine and Lhistidine plus $\beta$-alanine absorption tests were carried out in the two patients using methods previously described (Asatoor et al, 1970). Serum histidine, $\beta$-alanine, and carnosine were quantitatively assayed using the automatic ion exchange amino acid autoanalyzer (Beckman model 120C).

\section{Results}

Hydrolysis of carnosine followed the kinetics of zero order reaction, and the rate was proportional to the volume of homogenate in the reaction mixture. The optimum $\mathrm{pH}$ was around $\mathbf{8 . 0}$ and the activity was increased by about $70 \%$ with $0.001 \mathrm{M} \mathrm{Mn}^{++}$and completely inhibited by $0.001 \mathrm{M}$ cyanide in the reaction mixture. Carnosinase activity of the rat jejunal mucosa was somewhat lower than of the human jejunum (table I). Little or no enzyme activity could be detected in 10 human gastric and eight colonic biopsies, even when the tissue concentration in the reaction mixture was progressively increased six times. There was less carnosinase activity in the human duodenal compared with jejunal mucosa, and the enzyme appears to have only a fraction of activity against homocarnosine as a substrate compared with that for carnosine (table I). The mean carnosinase activity was 8.8 units in 15 patients with histologically normal jejunal mucosa, compared with the mean activity of 5.7 units in five patients with partial or subtotal villous atrophy. One of these five patients had subtotal villous atrophy from gluten-induced enteropathy and a markedly reduced level of carnosinase ( 2 units/g). Carnosine and amino acid absorption tests were carried out in this patient before treatment by a gluten-free diet. Repeat biopsies after several weeks on a gluten-free diet showed marked improvement of the jejunal histology and carnosinase activity in this and two other patients, and confirmed that the enzyme deficiency was nonspecific and secondary to the villous atrophy. The results of carnosine and amino acid tolerance tests in the two patients are shown in figures 1 and 2. As reported by Asatoor et al (1970), the rise in serum $\beta$-alanine at 30 minutes and of serum histidine at 30 and 45 minutes was much higher after the mixture of free amino acids than with carnosine in the patient with normal jejunal carnosinase activity. Absorption of both amino acids at 30 and 45 minutes was somewhat slower in

\begin{tabular}{|c|c|c|c|c|c|c|}
\hline & \multicolumn{3}{|c|}{$\begin{array}{l}\text { Carnosinase Activity } \\
\text { (units } / g \text { wet } w t)\end{array}$} & \multicolumn{3}{|c|}{$\begin{array}{l}\text { Activity for Homocarnosine } \\
\text { (units/g wet wt) }\end{array}$} \\
\hline & $\begin{array}{l}\text { No. } \\
\text { Assayed }\end{array}$ & $\begin{array}{l}\text { Range of } \\
\text { Activity }\end{array}$ & $\begin{array}{l}\text { Mean } \\
\text { Activity }\end{array}$ & $\begin{array}{l}\text { No. } \\
\text { Assayed }\end{array}$ & $\begin{array}{l}\text { Range of } \\
\text { Activity }\end{array}$ & $\begin{array}{l}\text { Mean } \\
\text { Activity }\end{array}$ \\
\hline Functional bowel disorders & 8 & $6 \cdot 3-10 \cdot 8$ & $8 \cdot 5$ & 3 & $4 \cdot 3-5 \cdot 3$ & $4 \cdot 6$ \\
\hline Organic gastrointestinal disorders & 7 & $7 \cdot 3-11 \cdot 2$ & $9 \cdot 1$ & 4 & $3 \cdot 7-6 \cdot 8$ & $4 \cdot 1$ \\
\hline Total with normal human jejunal histology & 15 & $6 \cdot 3-11 \cdot 2$ & $8 \cdot 8$ & 7 & $3 \cdot 7-6 \cdot 8$ & $4 \cdot 3$ \\
\hline $\begin{array}{l}\text { Human jejunum (partial or subtotal } \\
\text { villous atrophy) }\end{array}$ & 5 & $2 \cdot 0-8 \cdot 3$ & $5 \cdot 7$ & - & - & - \\
\hline Human duodenum & 10 & $2 \cdot 8-7 \cdot 2$ & $5 \cdot 7$ & 7 & $2 \cdot 2-4 \cdot 0$ & $3 \cdot 2$ \\
\hline Human stomach and colon & 18 & $0-0.05$ & - & - & - & - \\
\hline Rat jejunal mucosa & 8 & $1 \cdot 3-5 \cdot 2$ & $3 \cdot 7$ & - & - & - \\
\hline
\end{tabular}

Table I Carnosinase in human and rat mucosa 


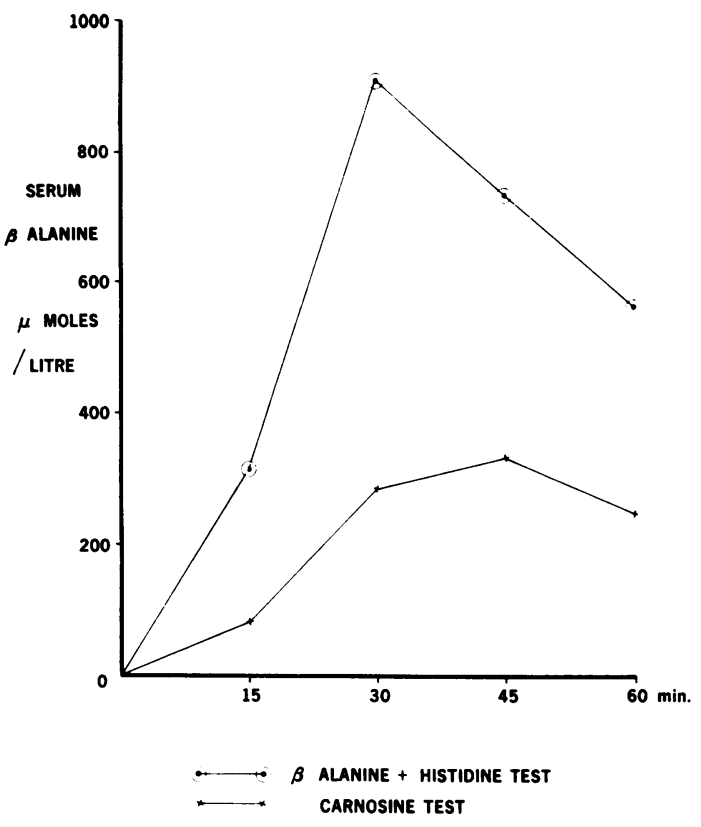

Fig 1 Rise in serum $\beta$-alanine in a patient with carnosinase deficiency.

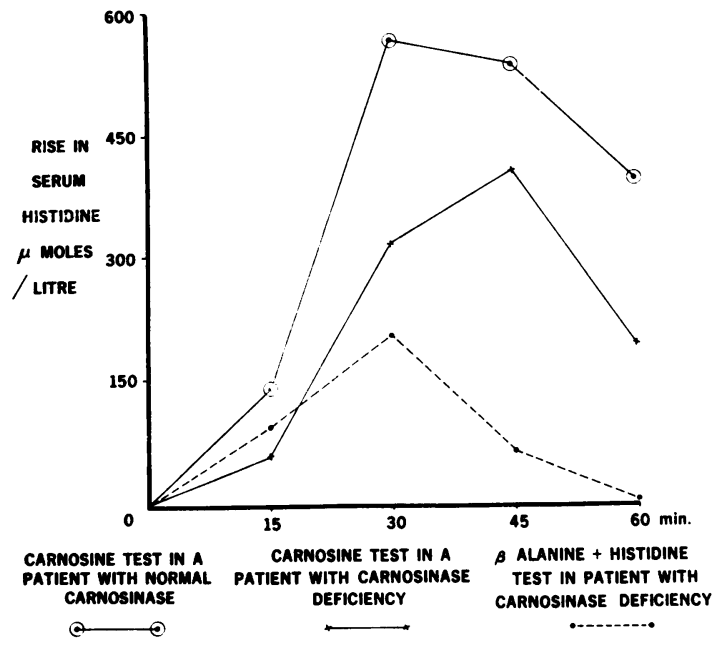

Fig 2 Rise in serum histidine with absorption tests.

the patient with reduced carnosinase than in the control patient, but despite the enzyme deficiency histidine absorption was faster with carnosine then with the free amino acids in this patient.

\section{Discussion}

The kinetic properties of the mucosal carnosinase,
pH optimum, its strong activation by $\mathrm{Mn}^{++}$and inhibition by cyanide suggest that the intestinal enzyme has similar properties to the carnosinase of swine kidney (Hanson and Smith, 1949). These authors found that carnosinase is a distinct enzyme with hydrolase activity against a wide range of histidine-containing dipeptidesincluding L-carnosine, glycyl L-histidine, L-alanyl L-histidine, anserine ( $\beta$-alanyl 1-methylhistidine), and some activity for L- $\alpha$-aminobutyryl L-histidine.

No data are available on the activity of carnosinase against homocarnosine ( $\gamma$-amino butyryl Lhistidine). Perry et al (1967) found markedly increased concentration of homocarnosine in the cerebrospinal fluid (CSF) of their two patients with carnosinaemia, and speculated that with carnosinase deficiency homocarnosine may accumulate in the brain at the expense of $\gamma$-amino butyric acid (GABA). Since GABA is thought to act as a transmitter at inhibitory synapses (Elliot, 1965), deficiency of this substance would cause a disease with prominent seizure activity. Increased levels of homocarnosine have also been reported in the CSF of untreated patients with phenylketonuria, and also in the cerebral white matter of one such patient (Allen, Tourtellotte, Adriaenssens, Lowenthal, and Mardens, 1968). More recently an adult patient with mental retardation, spasticity and markedly increased CSF concentration of homocarnosine has been described (Gjessing and Sjaastad, 1974). Our results suggest that the same intestinal enzyme is probably involved in hydrolysis of homocarnosine as carnosine, although its affinity for homocarnosine is only a fraction of that for carnosine (table I), a result which is consistent with the relatively less hydrolase activity of purified carnosinase of the swine kidney for $\alpha$-amino butyryl L-histidine (Hanson and Smith, 1949). Homocarnosine and small amounts of carnosine have been isolated from the brains of a number of mammalian species including man (Abraham, Pisano, and Udenfriend, 1962). Brain tissue can synthesize the two dipeptides (Yockey and Marshall, 1969), but it is not yet known if carnosinase is present in nerve tissue, although it is present in the liver, kidney and spleen (Garkavi, 1938; Hanson and Smith, 1949; Terplan and Cares, 1972), and human placenta (Zoch and Müller, 1971).

Little or no carnosinase activity was detected in gastric or colonic mucosa, while duodenal mucosa had less activity than the jejunum. The distribution of this dipeptidase in the human gastrointestinal mucosa is similar to that of the disaccharidases (Auricchio, Rubino, Semenza, Landolt, Kistler, and Prader, 1963), suggesting that the enzyme has a digestive function. Depressed levels of carnosinase 
were found in our patients with partial or subtotal villous atrophy, and activities increased with histological improvement of the jejunal mucosa in three patients with coeliac disease on a gluten-free diet. Reduced activities of other dipeptidases, such as glycylglycine and glycyl L-leucine (Douglas and Peters, 1970) and imido peptide hydrolases, have been previously reported in untreated coeliac disease (Heizer and Laster, 1970). The fall appears to be due to a non-specific effect of mucosal damage and villous atrophy, since the villi are known to have a high concentration of peptide hydrolases whilst the crypts have little enzyme activity (Nordstrom, Dahlqvist, and Josefsson, 1968; Cornell and Townley, 1973).

There was a significant delay in absorption of $\beta$ alanine from carnosine as compared with that from an equimolar mixture of the two amino acids in the patient with carnosinase deficiency (fig 1). However, absorption of histidine from carnosine was faster than when the free amino acids were given (fig. 2). This is a similar finding to that in a patient with Hartnup disease (Nava and Asatoor, 1970). The faster absorption of histidine from carnosine can only be explained if hydrolysis of the dipeptide occurs within, or at, the brush border of the intestinal mucosal cells, and confirms the role of the dipeptidase for absorption of carnosine. In-vitro experiments suggest that the intestinal mucosal cells possess separate uptake systems for peptides and amino acids (Matthews, Crampton, and Lis, 1971), and evidence has also been presented for active transport of carnosine, independent of its constituent amino acids, in the hamster small intestine (Addison, Burston, and Matthews, 1973).

We have not been able to assay jejunal carnosinase in healthy subjects, but the enzyme levels in relatively fit patients with functional bowel disorders did not differ significantly from those with organic disorders of the gastrointestinal tract but normal jejunal histology (table I). In our patient with normal jejunal carnosinase activity absorption of both histidine and $\beta$-alanine was somewhat faster from the mixture of amino acids than from carnosine, and the rise in serum $\beta$-alanine and histidine was of a similar order to that reported by Asatoor et al (1970) in healthy adults. These authors also found significantly faster absorption after ingestion of free amino acids than after the dipeptide, and their results suggested that although carnosine is absorbed as the entire molecule, subsequent hydrolysis is slow and is probably the rate-limiting step in the total absorptive process. The relatively low activity of carnosinase compared with that for glycylglycine and other dipeptidases in both the rat and human intestinal mucosa (table II) confirms this interpretation of their findings. By contrast hydrolysis of glycylglycine is relatively more rapid and does not cause a significant delay in the transport rate even when the amount of glycylglycine is three times the molar concentration of carnosine given in the absorption tests (Craft, Geddes, Hyde, Wise, and Matthews, 1968), unless there is a deficiency of glycylglycine dipeptidase caused by disease states (Sadikali, 1971).

Like Asatoor et al (1970) we could not detect intact carnosine in serum even of the patient with carnosinase deficiency, presumably because of carnosinase activity of human plasma and other tissues (Perry et al, 1968; Terplan and Cares, 1972). The former authors found a mean serum carnosinase activity of $19.5 \mu$ Moles of carnosine hydrolyzed per $\mathrm{ml}$ of serum in 16 hours. Using a more sensitive method and a shorter incubation period, the mean serum carnosinase activity in adults was determined as $44 \pm 14$ units/litre (Munster, van Trijbels, Heeswijk, Schut-Jansen, and Moerkerk, 1970). Carnosinase activity of jejunal mucosa by weight is therefore approximately 200 to 400 times that of normal human plasma. Carnosine and anserine are found in minimal amounts ( 2 to $3 \mathrm{mg}$ and 5 to $7 \mathrm{mg}$ per day respectively) in the urine of healthy subjects (Westall, 1955), but the excretion strongly depends on the intake of animal flesh in the diet (Block, Hubbard, and Steele, 1965). The hydrolytic capacity of the intestinal enzyme for carnosine and anserine can therefore be easily saturated in healthy adults by giving sufficient beef steak (which contains $0.03 \%$ carnosine by weight) or chicken breast (which contains both dipeptides). One or both dipeptides

\begin{tabular}{|c|c|c|c|c|}
\hline \multirow[t]{2}{*}{ Dipeptidase } & \multicolumn{2}{|c|}{ Rat Jejunum (Robinson and Shaw, 1960) } & \multicolumn{2}{|c|}{ Human Jejunum (Sadikali, 1971) } \\
\hline & $\begin{array}{l}\mu \text { Moles } / \mathrm{mg} \\
\text { Protein/10 Min }\end{array}$ & 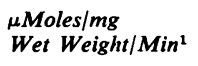 & $\begin{array}{l}\text { MMoles/mg } \\
\text { Wet Weight/Hour }\end{array}$ & $\begin{array}{l}\mu \text { Moles/mg } \\
\text { Wet Weight/Min }\end{array}$ \\
\hline $\begin{array}{l}\text { Glycylglycine } \\
\text { Glycyl L leucine } \\
\text { L-leucyl glycine }\end{array}$ & $\begin{array}{r}7 \cdot 0 \\
30 \cdot 5 \\
9 \cdot 6\end{array}$ & $\begin{array}{r}70^{1} \\
305^{1} \\
96^{1}\end{array}$ & $\begin{array}{r}5 \cdot 4 \\
63 \cdot 0 \\
6 \cdot 5\end{array}$ & $\begin{array}{r}90 \\
1500 \\
108\end{array}$ \\
\hline Carnosinase (present series) & & $3 \cdot 7$ & - & $8 \cdot 8$ \\
\hline
\end{tabular}

Table II Dipeptidases in human and rat jejunal mucosa

${ }^{1}$ For conversion of activities see Sadikali (1971). 
are then absorbed as such and can be detected in plasma, and large amounts are excreted unchanged in urine (Perry et al, 1967).

Excessive urinary excretion of carnosine even on a low protein diet has also been reported in patients with cerebromacular degeneration, and in their healthy adult relatives without neurological disease. Carnosinuria is apparently inherited as a dominant trait independently of cerebromacular degeneration (Bessman and Baldwin, 1962; Levenson, LindahlKiessling, and Raynor, 1964). The reason for excessive urinary excretion of carnosine in this condition, and whether there is a deficiency of carnosinase in the intestinal mucosa or other tissues is not known as yet. In hyper- $\beta$-alaninaemia carnosine accumulates in tissues, including the brain, due to a greatly expanded free $\beta$-alanine pool, and large amounts of carnosine are excreted in urine even on meat- and chicken-free diets (Scriver, Pueschel, and Davies, 1966).

We are grateful to Dr P. D. Gatfield, Children's Psychiatric Research Institute, London, Ontario, for the amino acid estimations.

\section{References}

Abraham, D., Pisano, J. J., and Udenfriend, S. (1962). The distribution of homocarnosine in mammals. Arch. Biochem., 99, 210-213.

Addison, J. M., Burston, D., and Matthews, D. M. (1973). Carnosine transport by hamster jejunum in vitro and its inhibition by other dipeptides and tripeptides. Clin. Sci., 45, 3P-4P.

Allen, R. J., Tourtellotte, W. W., Adriaenssens, D., Lowenthal, A., and Mardens, Y. (1968). Carnosinaemia. Lancet, 1, 1249.

Asatoor, A. M., Bandoh, J. K., Lant, A. F., Milne, M. D., and Navab, F. (1970). Intestinal absorption of carnosine and its constituent amino acids in man. Gut, 11, 250-254.

Auricchio, S., Rubino, A., Tosi, R., Semenza, G., Landolt, M., Kistler, H., and Prader, A. (1963). Disaccharidase activities in human intestinal mucosa. Enzymol. biol. Clin. (Basel), 3, 193 208.

Bessman, S. P., and Baldwin, R. I(1962). Imidazole aminoaciduria in cerebromacular degeneration. Science, 135, 789-791.

Block, W. D., Hubbard, R. W., and Steele, B. F. (1965). Excretion of histidine and histidine derivatives by human subjects ingesting protein from different sources. J. Nutr., 85, 419-425.

Cornell, H. J., and Townley, R. R. W. (1973). Investigation of possible intestinal peptidase deficiency in coeliac disease. Clin. chim. Acta, 43, 113-125.

Craft, I. L., Geddes, D., Hyde, C. W., Wise, I. J., and Matthews, D. M. (1968). Absorption and malabsorption of glycine and glycine peptides in man. Gut, 9, 425-437.

Crane, C. W. (1961). Some aspects of protein digestion and absorption in health and disease. Postgrad. med. J., 37, 745-754.

Douglas, A. P., and Peters, T. J. (1970). Peptide hydrolase activity of human intestinal mucosa in adult coeliac disease. Gut, 11, 15-17.

Elliot, K. A. C. (1965). $\gamma$-Aminobutyric acid and other inhibitory substances. Brit. med. Bull., 21, 70-75.

Garkavi, P. G. (1938). The splitting of carnosine under the influence of organs and tissues of the animal organism. Chem. Abstr. $32,8514$.
Gjessing, L. R, and Sjaastad, O. (1974). Homocarnosinosis: a new metabolic disorder associated with spasticity and mental retardation. Lancet, 2, 1028.

Hanson, H. T., and Smith, E. L. (1949). Carnosinase: an enzyme of the swine kidney. J. biol. Chem., 179, 789-801.

Heeswijk, P. J. van, Trijbels, J. M. F., Schretlen, E. D. A. M., Munster, P. J. J. van, and Monnens, L. A. H. (1969). A patient with deficiency of serum-carnosinase activity. Acta paediat. scand., 58, 584-592.

Heizer, W. D., and Laster, L. (1969). Peptide hydrolase activities of the mucosa of the human small intestine. J. clin. Invest., 48 , 210-228.

Levensen, J., Lindahl-Kiessling, K., and Raynor, S. (1964). Carnosine excretion in juvenile amaurotic idiocy. Lancet, 2, 756-757.

Matthews, D. M., Muir, G. G., and Baron, D. N. (1964). Estimation of alpha-amino nitrogen in plasma and urine by the calorimetric ninhydrin reaction. J. clin. Path., 17, 150-153.

Matthews, D. M. (1971). Experimental approach in chemical pathology. Brit. med. J., 3, 659-664.

Matthews, D. M., Crampton, R. F., and Lis, M. T. (1971). Sites of maximal intestinal absorptive capacity for amino acids and peptides: evidence for an independent peptide system or systems. J. clin. Path., 24, 882-883.

Meshkova, N. P., and Severin, S. E. (1947). The peculiar enzymic hydrolysis of carnosine. Chem. Abstr., 41, 6907.

Munster, P. J. J. van, Trijbels, J. M. F., Heeswijk, P. J. van, SchutJansen, B., and Moerkerk, C. (1970). A new sensitive method for determination of serum carnosinase activity using $L$ carnosine-(1-14C) $\beta$-alanyl as substrate. Clin. chim. Acta, 29 , 243-248.

Navab, F., and Asatoor, A. M. (1970). Studies in intestinal absorption of amino acids and a dipeptide in a case of Hartnup disease. Gut, 11, 373-379.

Newey, H., and Smyth, D. H. (1960). Intracellular hydrolysis of dipeptides during intestinal absorption. J. Physiol. (Lond.), 152, 367-380.

Nordstrom, C., Dahlqvist, A., and Josefsson, L. (1968). Quantitative determination of enzymes in different parts of the villi and crypts of rat small intestine. Comparison of alkaline phosphatase, disaccharidases, and dipeptidases. J. Histochem. Cytochem., 15, 713-721.

Perry, T. L., Hansen, S., Tischler, B., Bunting, R., and Berry, K. (1967). Carnosinemia: a new metabolic disorder associated with neurologic disease and mental defect. New Engl. J. Med., 277, 1219-1227.

Perry, T. L., Hansen, S., and Love, D. L. (1968). Serum-carnosinase deficiency in carnosinaemia. Lancet, $1,1229-1230$.

Rhodes, J. B., Eichholtz, A., and Crane, R. K. (1967). Studies in organization of the brush border in intestinal epithelial cells. IV. Aminopeptidase activity in microvillus membranes of hamster brush borders. Biochim. biophys. Acta (Amst.), 135 , 959-965.

Sadikali, F. (1971). Dipeptidase deficiency and malabsorption of glycylglycine in disease states. Gut, 12, 276-283.

Scriver, C. R., Pueschel, S., and Davies, E. (1966). Hyper $\beta$-alaninemia associated with $\beta$-aminoaciduria and $\gamma$-aminobutyricaciduria, somnolence and seizures. New Engl. J. Med., 274, 635-643.

Smith, E. L. (1951). The specificity of certain peptidases. Advanc. Enzymol., 12, 191-257.

Terplan, K. L., and Cares, H. L. (1972). Histopathology of the nervous system in carnosinase enzyme deficiency with mental retardation. Neurology (Minneap.), 22, 644-655.

Westall, R. G. (1955). The amino acids and other ampholytes of urine 3: unidentified substances excreted in normal urine. Biochem. J., 60, 247-255.

Wood, T. (1957). Carnosine and carnosinase in rat tissue. Nature (Lond.), 180, 39-40.

Yockey, W. C., and Marshall, F. D. (1969). Incorporation of ( $\left.{ }^{14} \mathrm{C}\right)$ Histidine into homocarnosine and carnosine of frog brain in, vivo and in vitro. Biochem. J., 114, 585-588.

Zoch, E., and Müller, H. (1971). Nachweiss und Bestimming von Carnosinase-Aktiortät der menschlichen Placenta. Enzymologia 40, 199-208. 